\title{
A busca pelo caminho de construção de uma Economia Política do Jornalismo
}

DOI: 10.1590/1809-58442017314

\section{Denise Freitas de Deus Soares}

(Universidade Federal do Piauí, Centro de Ciências da Educação, Programa de Pós-Graduação em Comunicação Social. Teresina - PI, Brasil)

DOURADO, Jacqueline; LOPES, Denise; MARQUES, Renan (Orgs.). Economia Política do Jornalismo: tendências, perspectivas e desenvolvimento regional. Teresina: EDUFPI, 2016.

Um esforço epistemológico para dar visibilidade aos estudos em Jornalismo e desenvolver, assim, um pensamento comunicacional crítico que abarque os fenômenos midiáticos em que vivemos. Assim pode ser definida a nova coletânea do grupo de pesquisa em Comunicação, Economia Política e Diversidade (COMUM), vinculado à Universidade Federal do Piauí, o livro "Economia Política

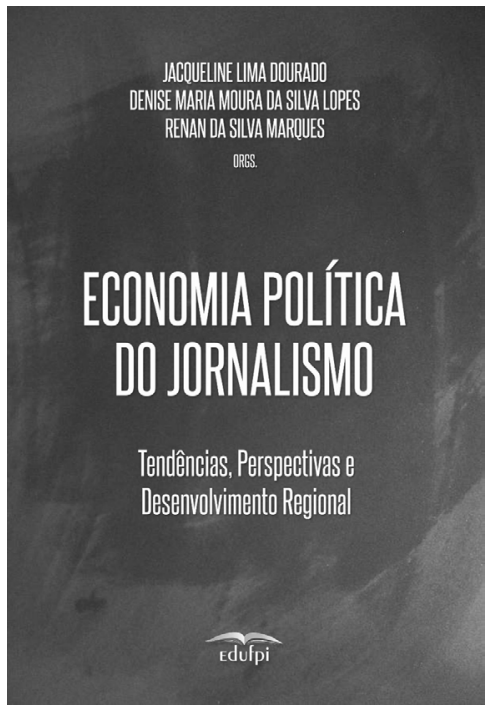
do Jornalismo: tendências, perspectivas e desenvolvimento regional” (2016).

A obra é compilada em 19 capítulos e traz questionamentos que apontam para o avanço salutar dos estudos em Comunicação no Brasil e no mundo. Seria a Economia Política do Jornalismo (EPJ) um subcampo da área ou mais um ponto de intersecção entre as ciências? Os pesquisadores desta obra realizaram um importante esforço no sentido de trazer à tona a discussão sobre o lugar do Jornalismo na área da Economia Política da Comunicação (EPC).

Logo no primeiro capítulo, Vincent Mosco revisita os clássicos conceitos da EPC para dar notoriedade à relação das cadeias produtivas no Jornalismo. Em acordo com Mosco, a fim de entender as transformações históricas e as mudanças sociais, a Economia Política tem atuado de modo a incluir como tendência atual a globalização do campo, reconhecendo a importância das novas formas de jornalismo, o destaque para os dispositivos tecnológicos e a ascensão das mídias sociais. Também nesse sentido Adílson Filho e Eula Cabral traçam um panorama analítico da realidade da mídia no Brasil a partir dos estudos da EPC. 
A César Bolaños interessa a investigação do período de expansão universitária, em paralelo com o avanço de formas de controle do trabalho docente complexificadas pela adoção de plataformas informatizadas. Ainda no âmbito laboral, há o artigo de Paulo Fernando Lopes e Adriana Magalhães, abordando a mercantilização de espaços noticiosos no jornalismo impresso piauiense de modo a produzir um modelo de jornalismo que coloca em xeque as principais características da própria atividade.

A obra também busca evidenciar as relações por meio das quais o jornalismo pode emperrar ou favorecer o desenvolvimento regional. Mary Landim e Jacqueline Dourado lançam mão da Economia Política como uma perspectiva teórica capaz de olhar a comunicação como fonte de promoção do desenvolvimento. Sônia Aguiar apresenta a experiência de uma associação temporária criada em 2000 por sete empresas jornalísticas da região Nordeste com o interesse de influenciar a agenda do desenvolvimento regional ao editar o suplemento Cadernos do Nordeste.

Já ao analisar a transformação estrutural dos meios de comunicação na Europa, moldada pelo fenômeno da convergência, Ainara Larrondo aponta oportunidades e também resistências diante do modelo de negócio tradicional. Seguindo essa abordagem baseada na tecnologia e nos desafios que trouxe às práticas jornalísticas, Carlos Franciscato apoia-se nos conceitos de inovação e desenvolvimento social para tentar desvendar os desafios da atividade laboral nas primeiras décadas do século XXI, além de apontar as possibilidades de interação disciplinar ao propor o entrecruzamento desses conceitos e modelos mediante renovadas experiências sociotécnicas. Juliana Teixeira, por sua vez, concentra esforços no sentido de analisar os efeitos dos dispositivos móveis em formas diferenciadas de produção, circulação e consumo dos conteúdos jornalísticos, com ênfase nos audiovisuais.

Ainda nessa linha de crescimento tecnológico e das telecomunicações, Samária Andrade pondera a prevalência na imprensa noticiosa como reflexo do avanço de um “jornalismo das indústrias culturais”. Diante dessa fase do jornalismo descrita pela autora, Leal Filho critica a academia ao falar que, em sua maioria, estudiosos têm dificuldade em perceber na mídia e no seu emaranhado de relações um ator político importante para o desfecho ou manutenção de crises.

No âmbito de efervescência política que agitou o Brasil em 2016, Denise Lopes, Cristal Sá e Jacqueline Dourado discutem os vieses norteados do jornalismo, de forma a promover uma espetacularização da notícia, sobretudo no episódio de divulgação das conversas telefônicas do ex-presidente Lula. Tal análise conduz, de certa forma, ao tema trabalhado por Patrícia Bandeira de Melo e Rodrigo de Assis: os meios de comunicação como espaços discursivos de poder em favor de interesses econômicos e políticos.

Na tentativa de entender esses discursos hegemônicos, Janaíne Aires e Susy dos Santos propõem o conceito de "coronelismo eletrônico", que ao longo dos anos concentrou as concessões de emissoras de serviços de radiodifusão nas mãos de determinados detentores, 
remetendo diretamente ao debate sobre a formação social e política do Brasil. Anderson dos Santos e Júlio Azevedo tratam, especificamente, da entrada do Sistema Opinião de Comunicação no mercado alagoano, ao adquirir parte da Sampaio Rádio e Televisão LTDA no período de digitalização da TV aberta. Sobre a regionalização, Joanne Mota apresenta um recorte da TV aberta em Sergipe, ao completar 45 anos, sem grandes novidades, tampouco independência, frente ao mercado nacional.

Ao analisar o discurso metaforizado acerca do vírus HIV, Andres Kalikoske alinha-se à compreensão que os processos de comunicação são interligados ao capitalismo, podendo, portanto, ser analisados sob o viés da EPC. Outra interessante temática trabalhada no livro, mais especificamente no capítulo de Renan Marques e Jacqueline Dourado, é a cidadania e como ela é abordada na comunicação piauiense, a partir do caso da Rede Clube, afiliada da Globo no Piauí.

Por fim, Inácio Macamo discute as possibilidades de realização de pesquisas inseridas na Economia Política do Jornalismo na realidade de Moçambique, região marcada pela exclusão social e pela pobreza. Na sua perspectiva crítica, a EPJ apresenta-se como uma possível saída para o despertar da consciência do público para a participação ativa em matéria de política nacional, a fim de que o descompasso entre Estado e sociedade civil moçambicana possa um dia se exaurir.

Assim, a obra "Economia Política do Jornalismo: tendências, perspectivas e desenvolvimento regional” traz uma relevante contribuição para os estudos em Jornalismo ao traçar um panorama da atividade praticada hoje em várias partes do Brasil e do mundo. Os textos da coletânea fustigam as implicações do jornalismo em termos de desenvolvimento regional, bem como ajudam a compreender a mercantilização da notícia como uma tendência global contemporânea.

\section{Denise Freitas de Deus Soares}

Mestranda do Programa de Pós-Graduação em Comunicação Social da Universidade Federal do Piauí. Especialista em Tendências e Perspectivas do Jornalismo e em Telejornalismo pela UFPI. Graduada em Comunicação Social com habilitação em Jornalismo pela UFPI. É membro do Grupo de Pesquisas em Comunicação, Economia Política e Diversidades - COMUM/UFPI. Tem como temas de interesse o mercado de TV e a Economia Política do Jornalismo. E-mail: denisefreitass@ hotmail.com.

Recebido em: 05.04.2017

Aceito em: 16.08.2017 